\title{
Self Regulated Learning Strategy and Goal Orientation towards Academic Procrastination in Practical Work Undergraduate Students of Civil Engineering Department
}

\author{
Mohammad Haqqi Abrian \\ abrianhaqqi@gmail.com \\ Industrial and Organization Psychology, Gunadarma University Graha Simatupang \\ Tower 1A, Jl. Letjend Tb. Simatupang Kav. 38 Jakarta Selatan
}

\begin{abstract}
Goal orientation and self regulated learning strategies are said to reduce academic procrastination behavior carried out by students. The purpose of this study was to find out the factors that led to academic procrastination in Civil Engineering students who were in practical work and how to overcome them. This study involved 50 Civil Engineering students who were in practical work. Multiple regression analysis is used to test the hypothesis in this study. The results showed that the goal orientation and self regulated learning had a positive relationship with academic procrastination in students. This means that if the goal orientation and self regulated are high, academic procrastination will also be high.
\end{abstract}

Keywords: goal orientation, self regulated learning, academic procrastination, and undergraduate students

\section{Introduction}

University is the last level in education. Every year the number of undergraduate students continues to increase, but this is not followed by the quality of education that is currently available. The current education system only teaches undergraduate students to understand theory without equipping them with skills and expertise which will certainly be useful in the future when undergraduate students enter the world of work. 
Research conducted by Damazier (2013) showed that by the end of 2012, the number of undergraduate unemployed has reached 780,000 people (Damazier, 2013), and may continue to grow as the years change. However, as time went by, several universities began to realize this phenomenon and began to equip their undergraduate students with programs called Practical Work (PW) such as at Gunadarma University, especially the Department of Civil and Planning Engineering. During the PW activity, students are given the opportunity to study in the field, deal with the object they learn directly, and are required and assigned to make observations, studies and analyzes the objects taken, comparing with the theories that have been obtained on campus, by examining in depth regarding various aspects of subjects related to conditions in the field.

When in practical work, undergraduate students remain active in classes on campus, thus undergraduate students must be able to manage their time to complete two tasks at the same time, namely classes and practical work. Setting the time between classes and practical work is one of the obstacles for undergraduate students who are in practical work. Practical work activities cause students to procrastinate completing university assignments and prioritize assignments from practical work.

One of the phenomena that often occurs in undergraduate students who delay completing work or assignments is called procrastination. Procrastination among undergraduate students in universities is very common and some studies have even found that more than $70 \%$ of undergraduate students admit that they procrastinate on a regular basis (Schraw et al., 2007).

In line with Schraw, research conducted by Ferrari (in Saraswati, 2017) shows that procrastination is one of the problems that afflicts most members of society at large, and students. Approximately $25 \%$ to $75 \%$ of students report that procrastination is a problem in their academic sphere. Procrastination which is usually carried out by undergraduate students is usually called academic procrastination, because procrastination affects undergraduate students' academic performances. 
Solomon and Rothblum (1984) defined academic procrastination as a delay in academic assignments for important tasks, for example, such as exam preparation, completing papers, presence (attendance), and when facing deadlines. The delay can be said to be a procrastination if the delay occurs on a task or something that is considered important, occurs repeatedly on purpose and causes feelings of discomfort. According to Ghufron and Risnawati (in Darmawan, 2017), the factors that influence academic procrastination can be categorized as two kinds, namely internal factors and external factors. Internal factors, namely the factors that exist within the individual that affect procrastination such as self-regulation in learning or self-regulated learning. Meanwhile, external factors, namely factors outside the individual that influence the tendency of procrastination in individuals, include parenting styles, environmental conditions, and social support.

Wolters (2003), explored the relationship between procrastination and selfregulated learning and found that metacognitive ability of self-regulated learning was the second strongest predictor of academic procrastination after academic selfefficacy. One of the factors that influence academic procrastination is self-regulated learning. This is supported by the results of research conducted by Wolters (2003) which showed that there is a relationship between academic procrastination and several important components of self-regulated learning. One of its components is cognitive which can be used by individuals to control cognition in the learning process. According to Zimmerman (1989) there are three processes that influence self-regulated learning, namely personal (self), environment and behavior. These three processes also have a significant effect on academic procrastination, this is supported by the research of Cahyadi (2016) which showed that self-efficacy, selfregulated learning and academic achievement have a positive relationship with academic procrastination.

Zimmerman (1989) argued that self-efficacy is a key variable that impacts self-regulated learning. On the other hand, self-efficacy is one of the factors causing procrastination, so that self-regulated learning can be used as a way to reduce 
procrastination. This statement is supported by research by Savira and Suharsono (2013) which added that there is a negative and very significant relationship between Self Regulated Learning and academic procrastination.

The self-regulated learning strategy itself consists of several components (Zimmerman \& Martinez-Pons, 1988), namely self-evaluating, organizing and transforming, goal setting and planning, seeking information, keeping records and monitoring, environment structuring, self-consequating, rehearing and memorizing, seeking social assistance, reviewing and records (Zimmerman, 1989). With some of these self-regulated learning strategies, it is expected to increase self-efficacy, selfcontrol, motivation, social support, skills and problem-solving styles which are factors that cause procrastination. Self-regulation strategies in high learning are expected to reduce the level of academic procrastination and increase high academic achievement as well (Saraswati, 2017).

Zimmerman (2008) defined self-regulated learning as a process by which undergraduate students activate and control cognition, behavior and feelings that are systematically oriented towards achieving goals. Self-regulation is applied because individuals have a goal to be achieved in their life and as proof to others. To achieve that goal, the individual must carry out strategies that make it easier for the individual. How individuals try to master something, and how individuals apply these skills and compare them to get more optimal achievement.

Goal orientation is developed specifically to explain how learning and performance in carrying out academic tasks. According to Schunk, Pintrich and Meece (2012) undergraduate students with goals and self-efficacy in achieving their desires tend to be involved in activities that they believe can support their desires by paying attention to processes, practicing remembering information, trying and surviving difficulties. In the goal orientation, there are two components that differentiate children's learning methods, namely: mastery goal and performance goal. Mastery goal is an undergraduate student orientation to master the learning 
subject, while performance goal is an undergradate student orientation to get better results than others.

According to Howell and Watson (2007) Goal orientation is a motivational component that has been tested and has a relationship with academic procrastination. Based on the results of previous research, procrastination has a negative relationship with the goal orientation approach, especially the learning goal orientation, which is a self-regulation process that can be adjusted according to the desire to develop.

Based on the description above, the researcher wants to know how much influence the goal orientation and self-regulated learning strategy can reduce academic procrastination in civil engineering undergraduate students who are in practical work. The objectives of this study are as follows: 1) Knowing the influence of goal orientation on academic procrastination; 2) Knowing the influence of selfregulated learning strategies on academic procrastination. 3) Goal orientation and self-regulated learning strategies influence academic procrastination.

\section{Research Method}

This study involved 50 undergraduate students as participants. Participants in this study were undergraduate students who studied at University $\mathrm{X}$ in the Greater Jakarta area. All research participants were undergraduate students of the Civil Engineering Department who were in Practical Work (PW). Participants in this study consisted of 26 men and 24 women. The ages of the participants ranged from 20 to 22 years old. The sample in this study was taken by purposive sampling, namely, the sample taken has been determined in advance by the researcher.

The academic procrastination scale used in this study uses the Academic Procrastination Scale (APS) belonging to McCloskey and Scielzo (2015). One example of an item on that scale is "I get distracted by other things that are more fun when I should be doing coursework." There are 5 answer options ranging from 1-5 ranging from Strongly Suitable to Very Unsuitable. This academic procrastination scale has 25 items. After calculating the discriminatory power of the items, there are 
5 items nulled. As a result, the number of items remaining is 31 with a reliability of 0.850 .

The self-regulated learning scale used in this study uses the Motivated Strategies for Learning Questionnaire (MSLQ) scale belonging to Pintrich and De Groot (1990). One example of an item on that scale is "I believe I do all my coursework better than my classmates". There are 5 answer options ranging from 1-5 ranging from Strongly Suitable to Very Unsuitable. This self-regulated learning scale has 34 items. After calculating the power of item discrimination, there are 3 items nulled. As a result, the number of items remaining is 31 with a reliability of 0.913 .

The goal orientation scale used in this study uses the Button, Mathieu and Zajac (1996) scale. One example of an item on this scale is "I feel smart when I do something without making the slightest mistake". There are 5 answer options ranging from 1-5 ranging from Strongly Suitable to Very Unsuitable. The goal orientation scale has 16 items. After calculating the item discrimination power, there are 3 items nulled. As a result, the number of items remaining is 13 with a reliability of 0.830 .

\section{Results}

Based on the results of the research that has been done, this study is normally distributed with a significance value of $0.200 \rho>.05$ ) for procrastination, then for goal orientation it has a significance of $0.200 \rho>.05$ ) and for self-regulated learning it has a significance of $0.038 \rho<.05$ ). This means that the relationship between the three variables has a linear (direct) relationship. 
Table 1. Results for self-regulated learning and goal orientation towards academic procrastination

\begin{tabular}{rrrr}
\hline $\mathrm{R}$ & R Square & Adjusted R Square & \multicolumn{2}{c}{$\begin{array}{c}\text { Std. Error of the } \\
\text { Estimate }\end{array}$} \\
\hline $.965^{\mathrm{a}}$ & .931 & .928 & 2.484
\end{tabular}

a. Predictors: (Constant), Goal Orientation, Self Regulated Learning

Table 2. Coefficients Correlation

\begin{tabular}{lcccccc}
\hline & \multicolumn{2}{c}{$\begin{array}{c}\text { Unstandardized } \\
\text { Coefficients }\end{array}$} & \multicolumn{2}{c}{$\begin{array}{c}\text { Standardized } \\
\text { Coefficients }\end{array}$} & & \\
\cline { 2 - 5 } Variable X & $\mathrm{B}$ & Std. Error & Beta & t & Sig. \\
\hline Goal Orientation & 1.237 & .077 & .888 & 16.146 & .000 \\
\hline Self Regulated Learning & .068 & .036 & .103 & 1.867 & .068 \\
\hline
\end{tabular}

Based on the table above, it can be seen that the closeness of the relationship between self-regulated learning and goal orientation towards academic procrastination with an $\mathrm{R}$ value of 0.965 . Meanwhile, the contribution of selfregulated learning and goal orientation to academic procrastination is $93 \%$ and the remaining $7 \%$ is another factor outside research that affects academic procrastination. Meanwhile, the correlation coefficient for goal orientation has a significance of 0.000 and self-regulated learning has a significance of 0.068 . In addition, goal orientation has a close relationship with academic procrastination with an $\mathrm{R}$ value of 0.962 and contributes $93 \%$ to academic procrastination. Thus, goal orientation has a significance value that is closest to 0.05 , where a variable can be said to be the most influential if it has a significance value $(\rho<.05)$. So, it can be concluded that the goal orientation variable has the greatest influence on academic procrastination compared to self-regulated learning.

Based on the research results, it can be seen that goal orientation, self regulated learning and academic procrastination have a positive relationship. This 
means that if the individual has a high goal orientation, the self-regulated learning strategy that is implemented will also be better. This also applies to academic procrastination. In this study, found the results that PW students majoring in Civil Engineering conducted active procrastination. The results of this study are supported by research conducted by Choi (2005) which states that procrastination can be divided into two, namely active procrastination and passive procrastination. Students who do active procrastination like to work under pressure, they like challenges and feel motivated. They are diligent and can complete the task near the end of time (a state of urgency).

Based on interviews that have been conducted with 5 undergraduate students as a sample of civil engineering students who are currently in PW (Practical Work), it is known that 3 out of 5 people are more concerned with PW than college, while 2 people say that PW and college must be balanced. Students majoring in Civil Engineering who are currently PW are more concerned with PW than lectures because the weight of the PW score is greater than in lectures, with a score of $60 \%$ while lectures are $40 \%$. Then, students have organized themselves as best as possible so that when students procrastinate lecture assignments and prioritize $\mathrm{PW}$, lecture assignments can still be completed before the collection assignment deadline. Damayanti (2015) in his research revealed that learning based on self-regulation can improve learning outcomes because these students will be more involved in the learning process, more participative in learning and have high motivation, active in doing assigned tasks, and have a sense of desire. know high. However, research conducted by Rohmaniyah (2018) on BEM members shows the opposite, namely, self-regulated learning has a negative relationship with procrastination in BEM members, which means that if BEM members have a strategy, planning and ability to share time, the less likely they are will do academic procrastination.

Based on the information above, there are several things that influence why civil engineering undergraduate students prefer PW, namely, according to Watson (in Zimmberoff \& Hartman, 2001) the initial causes of procrastination are related to fear 
of failure or self-efficacy, dislike of tasks that are given, contradict and against control (in this case the lecturer), and have dependency and difficulty in making decisions. However, there are several things that must be considered, namely that some undergraduate students prefer learning outdoors with practice rather than indoors with theory.

Wolters (2003) added that the factor that affects procrastination is selfefficacy, in his research it found that undergraduate students who are less confident in their abilities, especially in academics, will more often delay completing a task than students with higher self-efficacy. Undergraduate students with procrastination not only show low self-efficacy in terms of academic skills, but also show low selfefficacy in managing themselves well. The main factor that affects procrastination is self-efficacy, which is an individual's belief in the ability to complete a job well (Zimmerman, 2008). Then, Dweck and Legget (1988) added that conceptually selfefficacy (feeling confident in doing a task) and goal orientation (approach to learning) are two different things, but have a relationship for difficult tasks. The relationship between goal orientation and self-efficacy will affect the motivation process that individuals have. Individuals with high self-efficacy will seek challenges regardless of their goal orientation, although individuals with low self-efficacy will be motivated when they have a strong learning goal orientation.

Previous research has suggested that fear of failure or anxiety has a positive relationship with procrastination. Research conducted by Van Eerde (2003) found that individuals who feel afraid of failure or feel anxious about something will be more interested in making excuses to procrastinate. Fear of failure and social anxiety associated with procrastination. This is caused by stress affected by delays made by individuals in completing a task therefore it makes them suffer from tasks that keep coming afterwards.

Then, Wiyarti and Setyawan (2017) found in her research on Islamic boarding school students that one of the external factors that causes individuals to procrastinate is peer social support. Peer support has a negative effect with procrastination. This 
means that if positive peer support can reduce procrastination, and vice versa if negative peer support, then procrastination is higher to do. Procrastination carried out by individuals tends to be related to conformity (follow-along) to the social environment, if individuals with a lazy social environment, the level of proctastination will be higher, and vice versa. Baron and Byrne (2005) added that individuals conform because of their tendency to depend on others as sources of information and to avoid rejection or to be liked by others. It is not uncommon for undergraduate students to rely on their classmates by borrowing notebooks to copy what the lecturer explained in class or borrowing notes from friends and then copying them to study the day before the exam.

Other causes of procrastination according to Brothen and Wamback (2001) are because undergraduate students do not understand the instructions for the assigned task, the tasks are too difficult, undergraduate students are not sure where to start working on and how to complete their tasks properly. Other reasons are selfrejection, inappropriate emotions, where this feeling may not be on campus and tends to be more to the place where PW (practical work) students are. Procrastination is seen as a coping strategy for managing academic stress and has both positive and negative effects. The positive impact is to encourage individuals to raise awareness and produce new experiences, while the negative impact is to cause feelings of anxiety, worry, apprehensive, frustration, insecurity, anger, and depression.

\section{Conclusion and Suggestions}

Although many previous studies have found that academic procrastination has a negative relationship with self-regulated learning and goal orientation, this study finds the opposite, namely self-regulated learning and goal orientation have a positive relationship with academic procrastination. This means that if self-regulated learning and goal orientation are good, the academic procrastination are also high. Academic procrastination in this study is largely influenced by other factors outside of research that have a greater influence on self-regulated learning and goal orientation, such as 
self-efficacy, the role of peer support, conformity with the social environment, and the difficulty of assigned tasks. This finding adds to the variation from the findings of previous studies. In this study it shows that academic procrastination is a dynamic variable in studies that depend on independent variables that influence which will produce different results.

There are several suggestions that can be made regarding the results of this study. First, considering the independent variables that affect academic procrastination, it would be better to include an external variable that affects procrastination. Second, measuring demographic data to see which gender and age were the ones with the highest rates of procrastination among undergraduate students. Third, broadening the research subjects to at least 100 people and broadening the subject criteria not only civil engineering undergraduate students who are currently in PW but also undergraduate students of other departments who are currently doing PW. It may be possible to find more varied results on academic procrastination.

\section{References}

Baron, R.A., \& Byrne, D. (2005). Psikologi Sosial. Jakarta: Erlangga.

Brothen, S. P, \& Wambach, c. (2001). Procrastination and personality, performance and mood. Personality and Individual Differences, Vol. 30: 95-106.

Button, S. B., Mathieu, J. E., \& Zajac, D. M. (1996). Goal orientation in organizational research: A conceptual and empirical foundation. Organizational Behavior and Human Decision Processes, 67, 26-48.

Cahyadi, S. (2016). Hubungan Achievement Emotions dan Self-Regulation Mahasiswa Dalam Mengerjakan. Skripsi.

Choi, J.N. (2005). Rethinking Procrastination: Positive Effects of "Active" Procrastination Behavior on Attitudes and Performance. The Journal of Social Psychology. 145 (1), 242-250.

Damayanti, Eka. (2015). Peran Belajar Berdasar Regulasi Diri dan Penyesuaian Diri terhadap Prestasi Belajar Siswi Madrasah Tsanawiyah Muallimat Yogyakarta. Jurnal Biotek (online), Vol 3 No 2.

Damazier, Yutimah. Fenomena: Mahasiswa, Skripsi, dan Dunia Kerja. Diunduh pada 18 April 2015, dari: http://edukasi.kompasiana.com/2013/02/20/fenomena mahasiswa-skripsi-dan-dunia-kerja-530513.html. 
Darwaman, G. P. N. (2017). Pengaruh self-regulated learning terhadap prokrastinasi akademik mahasiswa jurusan pendidikan ekonomi. Jurnal Pendidikan, Vol. 2(02).

Dweck, C. S., \& Leggett, E. L. (1988). A social-cognitive approach to motivation and personality. Psychological Review, 95, 256-273.

Howell, A. J., \& Watson, D. C. (2007). Procrastination: Association with achievement goal orientation and learning strategies. Personal and Individual Differences, 43(1), 167-178.

McCloskey, J., \& Scielzo, S. A. (2015). Finally!: The Development and Validation of the Academic Procrastination Scale. Manuscript submitted for publication.

Pintrich, P.R., \& De Groot, V. (1990). Motivational and self-regulated learning components of classroom academic performance. Journal of Educational Psychology, Vol.82(1), 33-40.

Rohmaniyah, A. (2018). Hubungan antara self regulated learning dengan prokrastinasi akademik pada anggota BEM Universitas X. Jurnal Penelitian Psikologi, Vol.05 (02).

Saraswati, P. (2017). Strategi Self regulated learning dan prokrastinasi akademik terhadap prestasi akademik. Intuisi, Vol. 03, 210-223.

Savira \& Suharsono. (2013). Self-Regulated Learning (SRL) Dengan Prokrastnasi Akademik Pada Siswa Akselerasi. Jurnal Ilmiah Psikologi Terapan (JIPT), Vol. 1(1).

Schraw, G., Wadkins, T. \& Olafson, L. (2007). Doing the things we do: A grounded theory of academic procrastination. Journal of Educational Psychology, 99(1): 12-25.

Schunk, D.H. Pintrich, P. R, \& Mecce, L.J. (2012). Motivational In Education: theory, research, and application. Ohio: Pearson Press.

Solomon, L. J., dan Rothblum, E. J. (1984). Academic procrastination: Frequency and cognitive behavioral correlates. Journal of Counseling Psychology, 31, 503-509.

Van Eerde, W. (2003). A meta-analytically derived nomological network of procrastination. Personality and Individual Differences, 35(6), 1401-1418.

Wiyarti, H. A, \& Setyawan, H. (2017). Hubungan antara dukungan sosial teman sebaya dengan prokrastinasi menghafal al-qur'an pada santri di pondok pesantren modern islam assalaam surakarta. Jurnal Empati, 06(04): 33-36.

Wolters, C. A. (2003). Understanding procrastination from self-regulated learning perspective. Journal of Educational Psychology, 95(1), 179-187.

Zimberoff, D., \& Hartman, D. (2001). Four primary existential themes in HeartCentered Therapies. Journal of Heart Centered Therapies, 4(2), 3-3.

Zimmerman, B.J., \& Martinez-Pons, M. (1988). Construct validation of a strategy model of student self-regulated learning. Journal of Educational Psychology, 80, 284-290.

Zimmerman, B. J. (1989). A social cognitive view of self-regulated academic learning. Journal of Educational Psychology, Vol. 81, No. 3: 329-339. 
Zimmerman, B. J. (2008). Investigating self-regulation and motivation: historical background, methodological developments, and future prospects. American Educational Research Journal, 45 (1), 166-183. 